\title{
Effects of interannual environmental variability on the transport-retention dynamics in haddock Melanogrammus aeglefinus larvae on Georges Bank
}

\author{
Jason M. Boucher ${ }^{1, *}$, Changsheng Chen ${ }^{1}$, Yunfang Sun ${ }^{1}$, Robert. C. Beardsley ${ }^{2}$ \\ ${ }^{1}$ School for Marine Science and Technology, University of Massachusetts-Dartmouth, New Bedford, Massachussetts 02742, USA \\ ${ }^{2}$ Department of Physical Oceanography, Woods Hole Oceanographic Institution, Woods Hole, Massachussetts 02543, USA
}

\begin{abstract}
Georges Bank is a region of high biological productivity characterized by a welldefined clockwise tidal rectified circulation gyre. Fluctuations in the year-class strength of haddock Melanogrammus aeglefinus on Georges Bank have been attributed to mortality during the highly vulnerable larval stages. While predation and starvation greatly impact on survival, advection to unfavorable regions may result in greatly reduced numbers of individuals. For successful selfrecruitment to occur, individuals must remain within the shoal region of Georges Bank until settlement. An individual-based model (IBM) was utilized to estimate the retention of haddock eggs and larvae on Georges Bank annually for 1995 through 2009. The IBM was driven by the Finite-Volume Community Ocean Model (FVCOM) for the Gulf of Maine domain. Biological components of haddock larvae were omitted to restrict analyses to the impact of circulation on passive transport. Inflow over the Scotian Shelf and tidal interaction patterns were identified as the major drivers of variability in interannual transport-retention dynamics. The simulations indicated that retention rates were highest in 2000 and 2003, and lowest in 1997. The above-average retention in 2000 and 2003 with anomalously large recruitment only in 2003 indicates that high retention appears to be necessary but not sufficient to explain large recruitment events of haddock on Georges Bank.
\end{abstract}

KEY WORDS: Larval retention · Haddock · Modeling · Georges Bank · Bio-physical coupling · Fish early life history stages $\cdot$ Fish larvae

\section{INTRODUCTION}

Biological hotspots are ecologically important areas characterized by high biodiversity (species richness, abundance, and biomass) and high chlorophyll concentration (Hughes et al. 2002, Valavanis et al. 2004, Reese \& Brodeur 2006). Georges Bank exhibits both characteristics, with annual primary productivity in the tidally mixed shoals approaching 3 times the global mean value for continental shelves (O'Reilly et al. 1987). The high productivity on Georges Bank is caused by (1) the nutrient-rich deep waters surrounding the bank, (2) tidal mixing on the shoals incorporating the deep water nutrients into the tidal-mixing front zones, and (3) insignificant light limitation (Riley
1941, Horne et al. 1989, Franks \& Chen 1996, Townsend \& Pettigrew 1997).

Circulation in the Gulf of Maine-Georges Bank region is driven by a combination of local forcing (winds, heat flux, precipitation/evaporation, tides, and freshwater discharge from coastal rivers and groundwater) and remote forcing from upstream inflow and intrusion of Gulf Stream warm-core rings (Loder 1980, Smith et al. 2001, Hu 2009). Tidal currents over Georges Bank can exceed $100 \mathrm{~cm} \mathrm{~s}^{-1}$ and tidal rectification (interactions of tidal currents with steep bottom topography and tidal mixing) generates a permanent clockwise gyre around the bank (Fig. 1) (Loder 1980). Tidal-mixing fronts on Georges Bank are located around the $40 \mathrm{~m}$ isobaths on the northern flank and intensified by the shelf-break front on the 
southern flank at the $100 \mathrm{~m}$ isobath in winter and the 40-50 m isobaths in summer. As a result of seasonal intensification of tidal-mixing fronts, the clockwise gyre is strengthened by increasing stratification in late spring through summer (Chen et al. 1995) and varies on monthly, seasonal, and interannual time scales due to the fluctuation in river discharge and winds (Brink et al. 1987, Limeburner \& Beardsley 1996, Chen et al. 2001). The circulation system is directly controlled by southward transport on the Scotian Shelf and slope, which originates upstream from the Labrador Sea and Arctic Ocean (Chapman $\&$ Beardsley 1989). The interaction of the Gulf Streamassociated warm and salty water and the cooler, fresher Labrador slope water is a driver of the interannual variability in the circulation in the Gulf of Maine-Georges Bank region (Drinkwater \& Gilbert 2004).

Recruitment of highly fecund marine fishes is dependent on mortality through the egg and larval stages, mediated by starvation, predation, and advection away from the nursery area (Hjort 1914, Cushing 1974, Lasker 1975). Environmental variability in the key physical mechanisms that retain plankton, eggs, and larvae (Townsend \& Pettigrew 1996, Chen et al. 2001) has a pronounced influence on fish recruitment during the early larval stages (Bartsch \& Coombs 2001, 2004). Circulation, water temperature, and mixing can directly affect survival by impacting the spatio-temporal interaction of prey, predators, and settlement (Cushing 1974, Lasker 1975, Sale 1978).

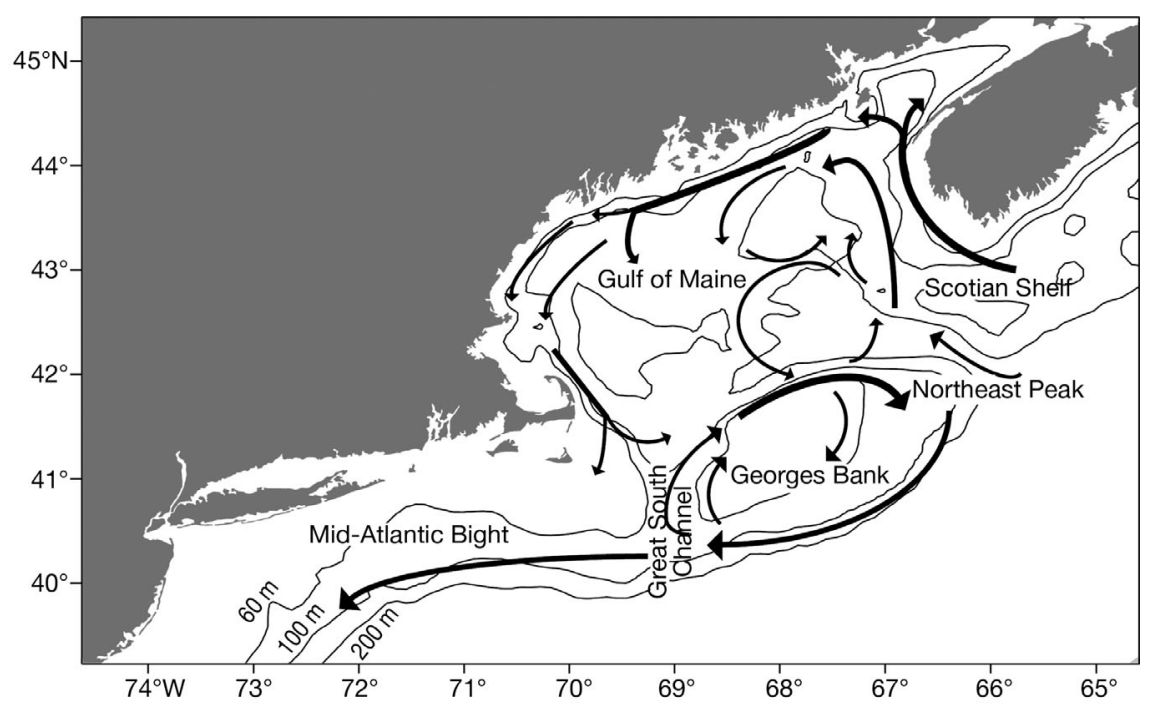

Fig. 1. General circulation patterns in the Gulf of Maine. The prominent gyre circulation on Georges Bank, enhanced by stratification and tidal interaction, produces enhanced chlorophyll concentration and biological productivity
Haddock Melanogrammus aeglefinus on Georges Bank spawn in the spring, from February through May (Smith \& Morse 1985), releasing eggs near the bottom (Hardy 1978, Page et al. 1989). Hatching occurs after 15 to $21 \mathrm{~d}$ and exogenous feeding begins 5 to 7 d later (Hardy 1978, Page \& Frank 1989). The clockwise gyre around Georges Bank retains haddock larvae within their nursery area, with losses transported towards the Mid-Atlantic Bight or entrained in the Gulf Stream warm core rings (Flierl \& Wroblewski 1985, Smith \& Morse 1985, Polacheck et al. 1992).

Recruitment into the Georges Bank haddock stock averaged 87 million fish annually between 1994 and 2002, with the 2003 year-class (the largest on record) exceeding 789 million age-1 recruits (Brodziak et al. 2006). Recruitment success, the ratio of the number of year-1 recruits to the previous year's spawning stock biomass (Churchill et al. 2011), fluctuates widely between years (Fig. 2) and is dependent on starvation, predation, and advective transport on Georges Bank. Strong year-classes of haddock are associated with circulation and retention on Georges Bank (Colton \& Temple 1961, Polacheck et al. 1992), with shoalward transport to the nursery region increasing with depth in the water column (Lough \& Bolz 1989, Werner et al. 1993). Wind stress enhances circulation off-bank, reducing recruitment as wind speed increases (Chase 1955, Lough et al. 1994, 2006, Mountain et al. 2008).

Individual-based models (IBMs) incorporate physical dynamics of the environment (circulation, advection, stratification, and turbulent mixing) with individual- and cohortlevel processes during the early life stages to infer relationships resolved in the model to observed patterns in the field (Bartsch \& Coombs 2004, Tian et al. 2009). IBMs of cod and haddock larvae in the Gulf of Maine have relied primarily on climatological circulation models, with variability in flow fields incorporated through the addition of monthlyaveraged wind-driven forcing (Werner et al. 1993, Brickman \& Frank 2000). However, circulation driven by climatological mean surface forcing is not representative of observed conditions in the Gulf of Maine-Georges Bank region, as wind stress and freshwater input change dramatically on short time scales (Miller 


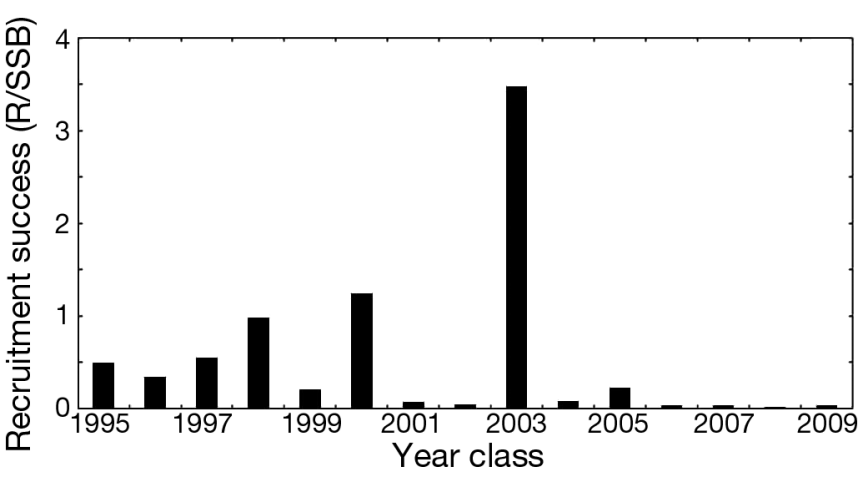

Fig. 2. Estimates of recruitment success of the Georges Bank haddock stock. Recruitment success (R/SSB) is the ratio of age-1 recruits $(R$, ind.) for a given year to the spawning stock biomass $(\mathrm{SSB}, \mathrm{kg})$ of the previous year

1946, Hopkins \& Raman 1987, Beardsley et al. 2003, $\mathrm{Hu}$ 2009). With the availability of circulation models capable of resolving interannual patterns, it is now possible to assess bio-physical interactions within and between years with increased accuracy.

Observational field ecology and modeling studies indicate the importance of interannual variation in circulation on the retention and survival of haddock on Georges Bank or on transport to the Mid-Atlantic Bight (Chase 1955, Polacheck et al. 1992, Lough et al. 1994). The purpose of the present study was to examine how interannual variation in the circulation of Georges Bank impacted on the distribution and retention of haddock larvae spawned on the Northeast Peak annually from 1995 through 2009. Our work follows an earlier study of larval haddock transport on Georges Bank (Werner et al. 1993) where particles were released on the Northeast Peak to determine the impact of advective transport on retention and settlement under climatological flow fields. Here we extend that analysis to include multiple years and investigate the impact of vertical turbulence in the water column with an advanced circulation model.

\section{METHODS}

\section{Circulation model}

The physical environment was represented using the prognostic free-surface, 3-dimensional (3D) primitive equation unstructured-grid, Finite-Volume Community Ocean Model (FVCOM) (Chen et al. 2006, 2007, 2011). The structure of this model is described in detail in Chen et al. (2011), and key components related to the current study are briefly provided. As a finite-volume model, FVCOM solves the governing equations in unstructured triangular volumes with a second-order accurate discrete flux scheme, resulting in more accurate representations of mass, momentum, heat, and salinity conservation (Chen et al. 2011). An unstructured triangular grid is used in the horizontal dimension, with terrainfollowing coordinates in the vertical. Vertical viscosity was computed using the Mellor and Yamada level-2.5 turbulence closure model (Mellor \& Yamada 1982) and the horizontal diffusion coefficient was determined using the Smagorinsky turbulent closure scheme (Smagorinsky 1963).

Two versions of the Gulf of Maine-FVCOM (GoMFVCOM) are utilized in this study. The GoM1FVCOM was configured for the Gulf of Maine with a cutoff at a depth of $300 \mathrm{~m}$ off the shelf break. This model was driven by local forcing including: (1) tides (constructed at the open boundary using 5 tidal constituents: $\mathrm{M}_{2}, \mathrm{~S}_{2}, \mathrm{~N}_{2}, \mathrm{~K}_{1}$, and $\mathrm{O}_{1}$ ), (2) sea surface interactions (wind stress, net heat flux plus shortwave irradiance, atmospheric pressure gradient, and precipitation/evaporation), and (3) freshwater discharges from the major coastal rivers of the Gulf of Maine. The computational domain encompasses the Gulf of Maine-Georges Bank region, bounded by the Scotian Shelf to the northeast and the New England Shelf to the southwest (Fig. 3). The domain was arranged by an unstructured triangular grid with a horizontal resolution varying from $\sim 0.5-1.0 \mathrm{~km}$ in the tidal-mixing front on Georges Bank to $\sim 10 \mathrm{~km}$ near the open boundary. Vertical resolution was divided into 31 levels, providing a variable depth per layer ranging from $\sim 1.5 \mathrm{~m}$ over the top of the Bank to $10 \mathrm{~m}$ offshore of the continental shelf where the bathymetry was truncated to $300 \mathrm{~m}$. The second version, GoM3-FVCOM, was configured as a global-regional nested model system with the same local forcing as GoM1-FVCOM, but the open boundary is specified using the output of the global FVCOM hindcast model simulation (Sun et al. 2013). This nested model system uses the real ocean bathymetry without a depth cutoff at the shelf break. The computational domain is extended to the south with coverage to Cape Hatteras, North Carolina, a horizontal resolution up to $0.3-0.5 \mathrm{~km}$ at the shelf break of Georges Bank and a total of 41 levels in the vertical.

Both GoM1-FVCOM and GoM3-FVCOM predicted 3D fields of water temperature, currents, and vertical viscosity, which were used to drive the IBM. The GoM1-FVCOM output provided physical forcing for simulations of interannual variability in retention caused primarily by local drivers of circulation for 


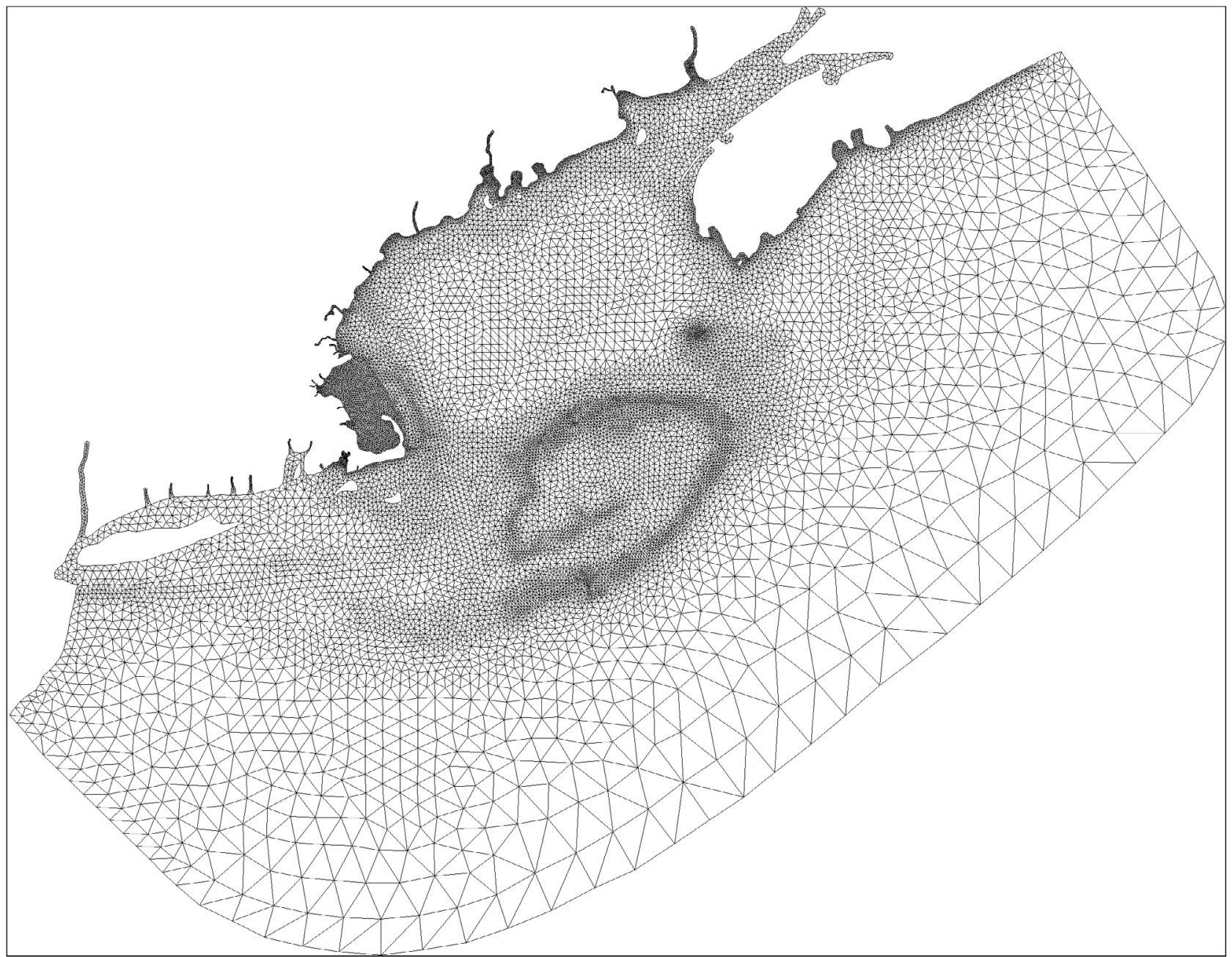

Fig. 3. Domain and mesh grid of the first Gulf of Maine Finite Volume Community Ocean Model (GoM1-FVCOM). The high resolution on Georges Bank enables greater replication of local dynamics

1995-2009. GoM3-FVCOM simulated the combined influence of local and remote drivers, but model output was only available for the 1997 and 1998 forcing fields. Use of the 2 circulation models enabled comparison of local and remote forcing on the transportretention dynamics of haddock eggs and larvae on Georges Bank.

\section{Individual-based model}

The IBM is described following the 'Overview, Design Concepts, and Details' (ODD) protocol of Grimm et al. (2006).

Purpose: A spatially-explicit individual-based model was developed to simulate the passive transport-retention dynamics experienced by haddock eggs and larvae from spawning until juvenile settle- ment on Georges Bank. The IBM was designed to track the impacts of the dynamic physical environment in the absence of larval behavior.

State variables \& scales: No biological state variables were included for the tracking of passive particles. We assumed that all individuals have no swimming ability or biological attributes, which may be appropriate only for the first $30 \mathrm{~d}$ (Auditore et al. 1994).

Process overview \& scheduling: Individuals were advected throughout the domain by the 3D circulation fields from FVCOM and tracked by the Lagrangian particle tracking algorithm. No foraging, growth, behavior or mortality processes were included.

Design concepts: Individual haddock eggs were released on the spawning grounds and tracked for the $90 \mathrm{~d}$ duration of their pelagic phases. Passive individuals were transported by a 3D Lagrangian 
flow. Passive individuals were utilized to elucidate the impact of interannual variability in circulation on transport in the absence of biological mediation.

Model data: For each time step (1 h), the particle position and depth, as well as temperature, salinity, and density at each particle location were updated. The recorded information for all individuals was combined to derive properties and characteristics at the population level.

Initialization: The IBM was initialized at the spawning of haddock on Georges Bank. Spawning events were simulated to occur over a $7 \mathrm{~d}$ period, released with a normal distribution in time. The normal distribution function of Tian et al. (2009) is used:

$$
e_{i}(t)=N S_{e} \int_{t_{0}}^{t} \frac{1}{\sqrt{2 \pi \sigma}} \mathrm{e}^{-\frac{1}{2}\left(\frac{t-t_{\mathrm{M}}}{\sigma}\right)} \mathrm{d} t
$$

where $e_{i}(t)$ is the number of eggs spawned by the $i$ th individual female adult at the time $t, N$ is the total number of females, $S_{\mathrm{e}}$ is the total numbers of eggs spawned by each individual adult in a spawning season, $t_{0}$ is the start time of spawning, $t_{\mathrm{M}}$ is the maximum spawning time, and $\sigma$ is the standard deviation.

Spawning location was based on a prior modeling study (Werner et al. 1993), with spawning period inferred from analyses of large-scale sampling programs (Smith \& Morse 1985, Sibunka et al. 2006). The median spawning date was set to March 29 for each year, with particles released from a grid on the Northeast Peak of Georges Bank. Particles were released at $1,10,30$, and $50 \mathrm{~m}$ depths and tracked for $90 \mathrm{~d}$, to account for the egg and larval stages of haddock up to settlement (Werner et al. 1993, Brickman 2003). Successful retention and settlement occurred if individuals remained within the $100 \mathrm{~m}$ isobaths and east of the Great South Channel $\left(68.86^{\circ} \mathrm{W}\right)$ by the end of the simulation.

Input: The 3D flow fields, water temperature, vertical eddy viscosity, horizontal mixing coefficients, and upwelling index were generated by the GoMFVCOM models.

Model assumptions: It was necessary to make some assumptions in order to use the physical model output and the biological data. It was assumed that no behavior capable of altering the position of the larvae was possible. While this may not be valid over the entire period of development, it was necessary to assume this to determine the variability that the environment alone can impart to the retention of eggs and larvae. It was also assumed that circulation on Georges Bank was accurately represented by the offline model velocity fields produced by FVCOM (see Chen et al. 2011 for details).

\section{Submodels}

The movement of individuals was controlled by a 3D Lagrangian flow, with the option to include vertical shear turbulence through the random walk formulation of Visser (1997) (adapted from Li et al. unpubl.):

$$
P_{n}(\vec{x}, t)=\int_{t-\Delta t}^{t} \vec{v} \mathrm{~d} t+R\left(K_{\mathrm{m}}\right)+P\left(\vec{x}_{t-\Delta t}, t-\Delta t\right)
$$

where $P_{n}(\vec{x}, t)$ and $P\left(\vec{x}_{t-\Delta t}, t-\Delta t\right)$ are the locations of the $n$th individual at times $t$ and $t-\Delta t_{i} \vec{v}$ is the 3D velocity vector; $R$ is a random process with mean $\left(R^{2}=0\right)$ and standard deviation $\left(R^{2}=\mathrm{r}\right), K_{\mathrm{m}}$ is the maximum diffusivity during the time interval, and $R\left(K_{\mathrm{m}}\right)$ is the vertical random walk distance moved during the time interval $(\Delta t)$. The advective distance was calculated by a modified 4th-order Runge-Kutta time-stepping scheme (Chen et al. 2003). A vertical random walk was simulated following the Visser (1997) differential equation with a time step of $\delta t$. Where $\hat{n}$ is the random walk time step at time $t-\Delta t$, the vertical location of the $n$th individual caused by the random walk after $\delta t$ is computed by:

$$
z_{\hat{n}+1}=z_{\hat{n}}+K_{\mathrm{m}}^{\prime} \delta t+r\left[2 \sigma_{z}^{-1} K_{\mathrm{m}}\left(z_{\hat{n}}+0.5 K_{\mathrm{m}}^{\prime} \delta t\right) \delta t\right]^{1 / 2}
$$

where $K_{\mathrm{m}}^{\prime} \delta t=\delta K_{\mathrm{m}} / \delta z, r$ is a random process with mean $=0$, and $\sigma_{z}$ is the standard deviation. Assuming that $r$ represents a uniform distribution between +1 and $-1, \sigma_{z}=1 / 3$. The random walk generator requires $\delta t$ to be much smaller than $\Delta t$ (the Lagrangian integral time scale) to prevent an unrealistic aggregation of individuals (Chen et al. 2003). In the present study, $\Delta t=120 \mathrm{~s}$, and $\delta t=6 \mathrm{~s}$, so that $R\left(K_{\mathrm{m}}\right)=z_{\hat{n}+20}-z_{\hat{n}}$, where $z_{\hat{n}}$ is the vertical location of the $n$th individual at $t-\Delta t$.

\section{Simulation experiments}

An experiment was conducted to examine how spatial and temporal variability of the environment affects transport and potential settlement of larvae interannually, as an extension to the climatological results of Werner et al. (1993), who suggested that interannual variability in larval distributions and circulation would produce variable losses from Georges Bank. Individuals were simulated to drift for $90 \mathrm{~d}$ after spawning in each experiment. A 2-dimensional (2D) model was utilized to determine the impact of fixed depth on the advection of larvae around Georges Bank. Next, a 3D tracking simulation was performed to simulate vertical dispersal in the water 
column due to bio-physical interactions. Persistence at depth will alter particle dispersal patterns and retention, requiring $3 \mathrm{D}$ advection of individuals. Two physical conditions were compared: (1) advection from the FVCOM circulation fields and (2) advection with the inclusion of vertical turbulence. Physical dynamics of a high and a low retention year were then compared to elucidate the components of the environment that may contribute to successful yearclasses of haddock on Georges Bank. The importance of remote forcing on retention was tested using the GoM3-FVCOM forcing for 1997 and 1998 as test cases with (1) 2D, (2) 3D, and (3) 3D with vertical turbulence, scenarios.

Recruitment is a complex process involving spawning dynamics (spawning stock biomass, fecundity, and nutritional state) as well as losses of the early life history stages (Hjort 1914, Cushing 1974, Lasker 1975). Small, almost imperceptible changes in larval growth or mortality rates can drastically alter recruitment, making prediction difficult and unreliable (Rothschild 1986, Beyer 1989). In an attempt to relate retention rates to prediction of recruitment, model retention rates were compared to recruitment success of the Georges Bank haddock stock (Churchill et al. 2011, NFSC 2012).

\section{RESULTS}

Interannual variability in larval haddock retention occurred in the $2 \mathrm{D}, 3 \mathrm{D}$, and $3 \mathrm{D}$ with vertical turbulence, simulations (Fig. 4). Similar trends were obtained from the 3 scenarios, with lowest retention in
1997 and 1998 and highest retention in 2000, 2003, and 2004. Mean retention between the 3 scenarios exhibited high variability within a year, ranging from a $24 \%$ difference in 2008 to $4 \%$ in 2009 (Fig. 4).

\section{D tracking}

A pattern of increased retention with increasing release depth was observed for all years in this study. Highest retention occurred for individuals constrained to the $50 \mathrm{~m}$ depth, and lowest for individuals at $1 \mathrm{~m}$. After $30 \mathrm{~d}$, retention of individuals released at $1 \mathrm{~m}$ ranged from $0.25 \%$ in 1997 to $92.97 \%$ in 1995 ; while retention exceeded $90 \%$ for all years when individuals were retained at $50 \mathrm{~m}$. By Day 90, retention at $1 \mathrm{~m}$ was less than $1 \%$ in 8 of the years and had decreased to $21.88 \%$ in 1995 . In contrast, the lowest retention at $50 \mathrm{~m}$ was $18.03 \%$ in 1998 and the highest was $96.32 \%$ in 2000 . These results are consistent with climatological modeling studies (Werner et al. 1993, Lough et al. 1994), where higher retention occurred when particles were released at $30 \mathrm{~m}$ or deeper.

\section{D tracking}

The pattern of increased retention for individuals released at $30 \mathrm{~m}$ or deeper was also observed in the 3D simulations, with dispersal throughout the water column impacting transport speed and direction. Retention of individuals released at $1 \mathrm{~m}$ after $90 \mathrm{~d}$ ranged from $0.00 \%$ (1997) to $24.60 \%$ (1995), while

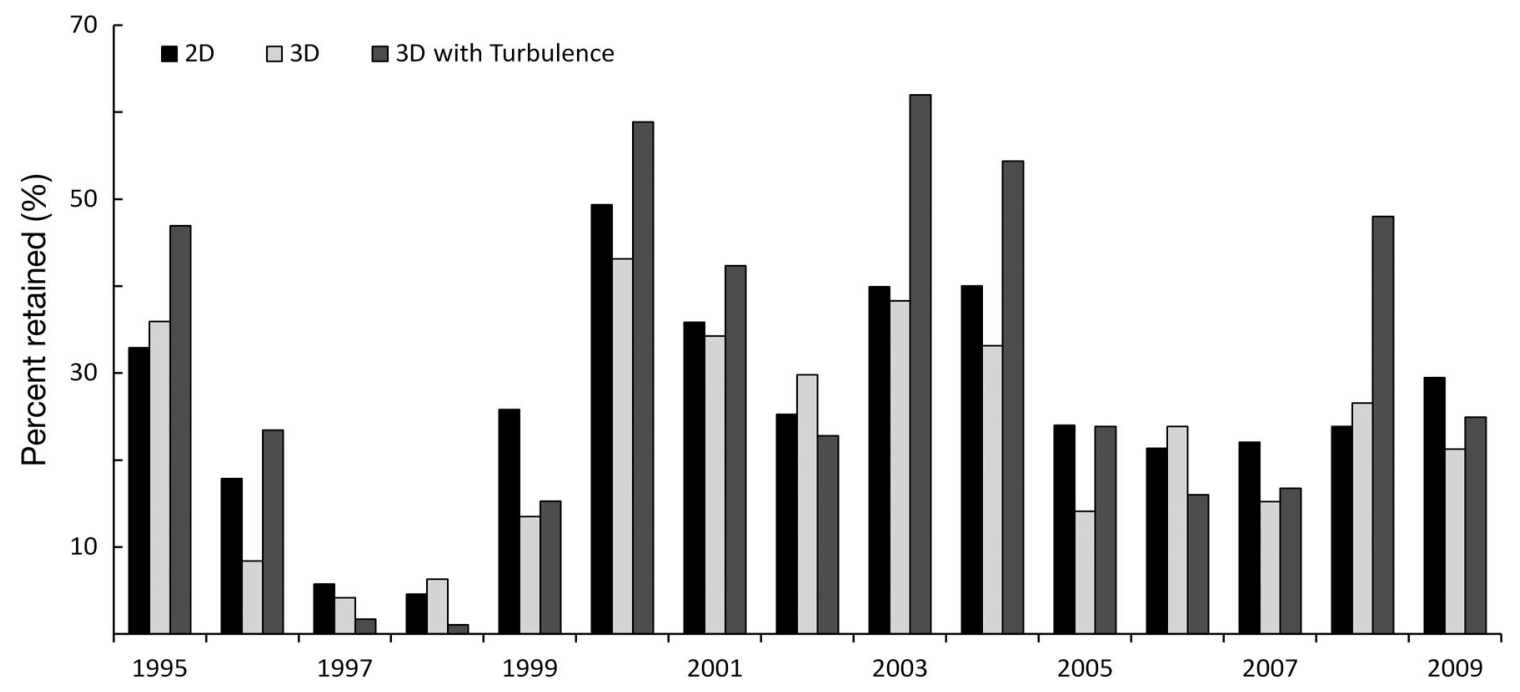

Fig. 4. Comparison of depth-averaged annual retention rates on Georges Bank after 90 d determined from GoM1-FVCOM simulations of 2-dimensional (2D) advection, 3-dimensional (3D) advection, and 3D advection with vertical turbulence 
retention of individuals released at the $50 \mathrm{~m}$ depth ranged from $16.61 \%$ (1997) to $76.28 \%$ (2000).

\section{D tracking with vertical turbulence}

The highly energetic environment and substantial vertical mixing of Georges Bank necessitated the inclusion of an artificial turbulence formulation to approximate non-linearity in the vertical dispersion of the system. When turbulence was included, the release depth had a negligible impact on retention compared to the $2 \mathrm{D}$ or $3 \mathrm{D}$ simulations. After $90 \mathrm{~d}$, retention was lowest in 1997, ranging from $1.98 \%$ for individuals released at $1 \mathrm{~m}$ to $1.41 \%$ for individuals released at $50 \mathrm{~m}$. Highest retention occurred in 2003, ranging from $61.26 \%$ at $1 \mathrm{~m}$ to $61.75 \%$ at $50 \mathrm{~m}$.

Utilizing the 3D tracking with vertical turbulence, substantial interannual variability in the spatial distribution and retention of haddock eggs and larvae occurred on Georges Bank from 1995 to 2009 (Fig. 5). Highest retention within the $100 \mathrm{~m}$ isobath occurred in 1995, 2000, 2003, 2004 and 2008. During these years, decreased velocity of the gyre resulted in reduced transport off of Georges Bank. The reduced circulation increased transport to the shoals in these years as well, with greater than $40 \%$ occurring within the $60 \mathrm{~m}$ isobath (shoals) after $90 \mathrm{~d}$. The depthdistribution of individuals indicated that 43 to $54 \%$ of all individuals retained on Georges Bank occurred in the upper $20 \mathrm{~m}$ of the water column at the end of the simulation.

Depth-dependent transport (2D/3D) in 2003 produced high retention of individuals released at the 30 and $50 \mathrm{~m}$ depths, with a primary loss route to the Mid-Atlantic Bight. Additional losses off the edges of the Bank were due to the 'leaky' gyre in 2003 (Fig. S1 in the Supplement at www.int-res.com/articles/suppl/ m487p201_supp.pdf). With vertical turbulence, a greater number of individuals are recirculated around the bank and advected toward the shoals. Lowest retention occurred in 1997, with less than $2 \%$ of individuals retained on Georges Bank. Spawning at $50 \mathrm{~m}$ and persistence in water $50 \mathrm{~m}$ or deeper increased the potential for individuals to be retained (Fig. S2 in the Supplement).

\section{Local and remote forcing}

The IBM was updated with GoM3-FVCOM physical forcing for 1997 and 1998 to provide a comparison of the contribution of local and remote forcing on retention. Both years produced low retention estimates with GoM1-FVCOM, which increased with the addition of remote forcing. Retention from the 3D tracking with vertical turbulence simulations increased from 1.72 to $15.45 \%$ for 1997 (Fig. S3 in the Supplement), while retention in 1998 increased from $1.08 \%$ with GoM1-FVCOM to over $31.02 \%$ with GoM3-FVCOM (Fig. 6). Greater retention in 1998 with GoM3-FVCOM physical forcing occurred at all depths as a result of changes in current direction and speed compared to GoM1-FVCOM (Fig. S4 in the Supplement).

\section{Comparison to recruitment}

Increased recruitment success appeared weakly related to increased retention over the period 1995 to 2009 (Table 1). The 2003 recruitment event for Georges Bank haddock exhibited the highest recruitment success and model retention rates. Although retention in 2003 exceeded all other years in this study, comparable estimates were obtained for 2000 and 2004, which did not exhibit comparably large recruitment events. The $4 \mathrm{yr}$ with highest retention were 2003, 2000, 2004, and 2008 (61.97, 58.89, 54.37, and $47.99 \%$, respectively), while the highest recruitment success occurred in 2003, 2000, 1998, and 1997 $(3.46,1.23,0.97$, and 0.54 , respectively). The $2 \mathrm{yr}$ with highest recruitment success also exhibited high model retention, but there is a disconnection between retention rate and recruitment success in most years.

\section{DISCUSSION}

IBMs of haddock larvae on Georges Bank have not reexamined the impact of currents and advection on the retention of individuals since the study of Werner et al. (1993), even though substantial progress in circulation models has occurred. The general pattern of increased retention with increasing depth established by Werner et al. (1993) was reproduced in the present study with both the GoM1-FVCOM and GoM3FVCOM physical models. Although their results indicate that a directional swimming capability significantly enhanced shoalward displacement of larvae, the model-predicted circulation processes on Georges Bank produced a similar response for passive larvae, which varied substantially between years (Fig. 5).

The use of a turbulent formulation has become standard practice for IBMs simulating foraging of fish larvae (see Werner et al. 1996, 2001, Vikebo et al. 

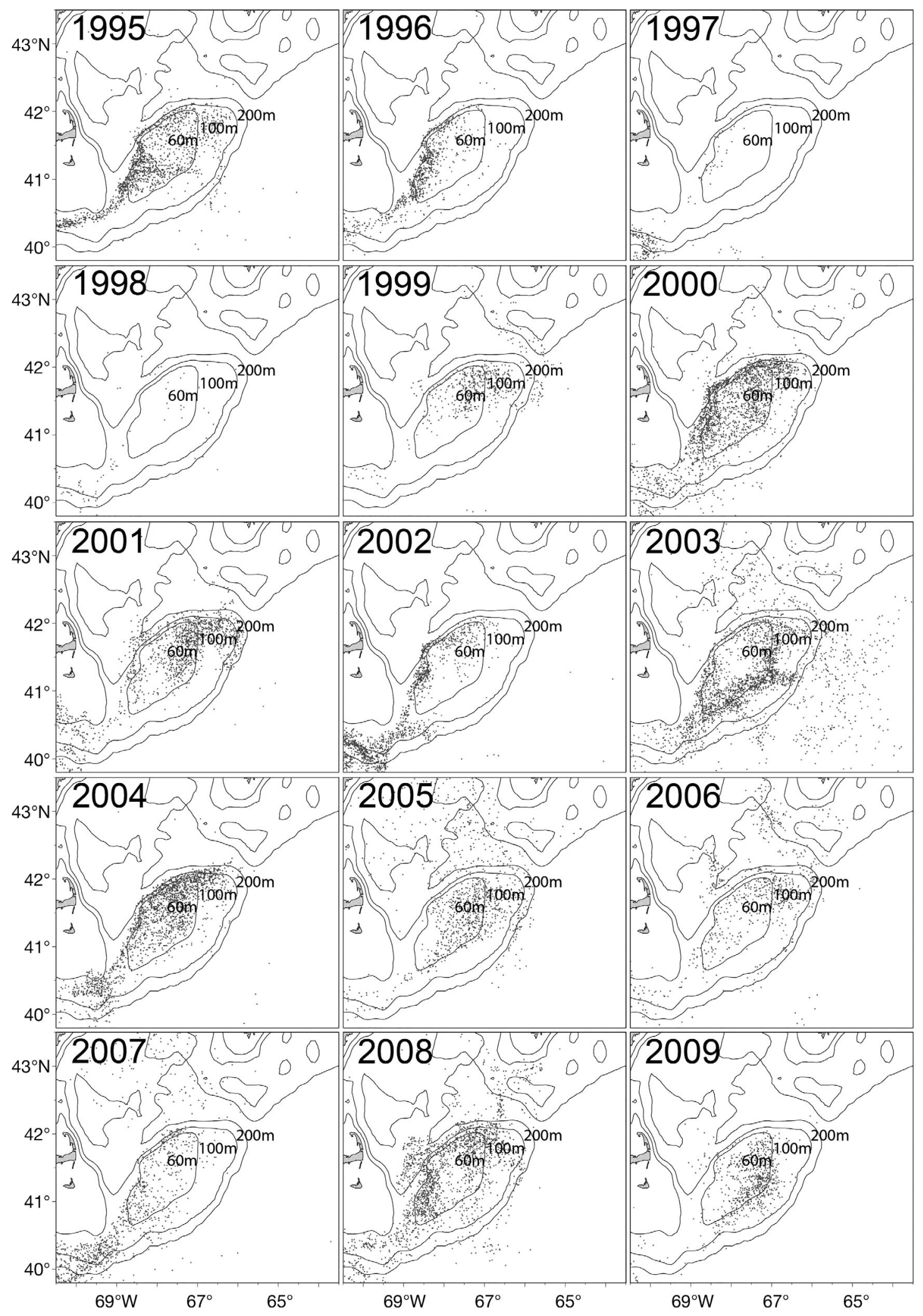

Fig. 5. Simulated depth-averaged distribution of particles $90 \mathrm{~d}$ after release during March on the Northeast Peak of Georges Bank, from 1995 through 2009, with GoM1-FVCOM physical forcing. Slower gyre circulation in 1995, 2000, 2003, and 2004 results in increased particle retention on Georges Bank and settlement to the shoals 


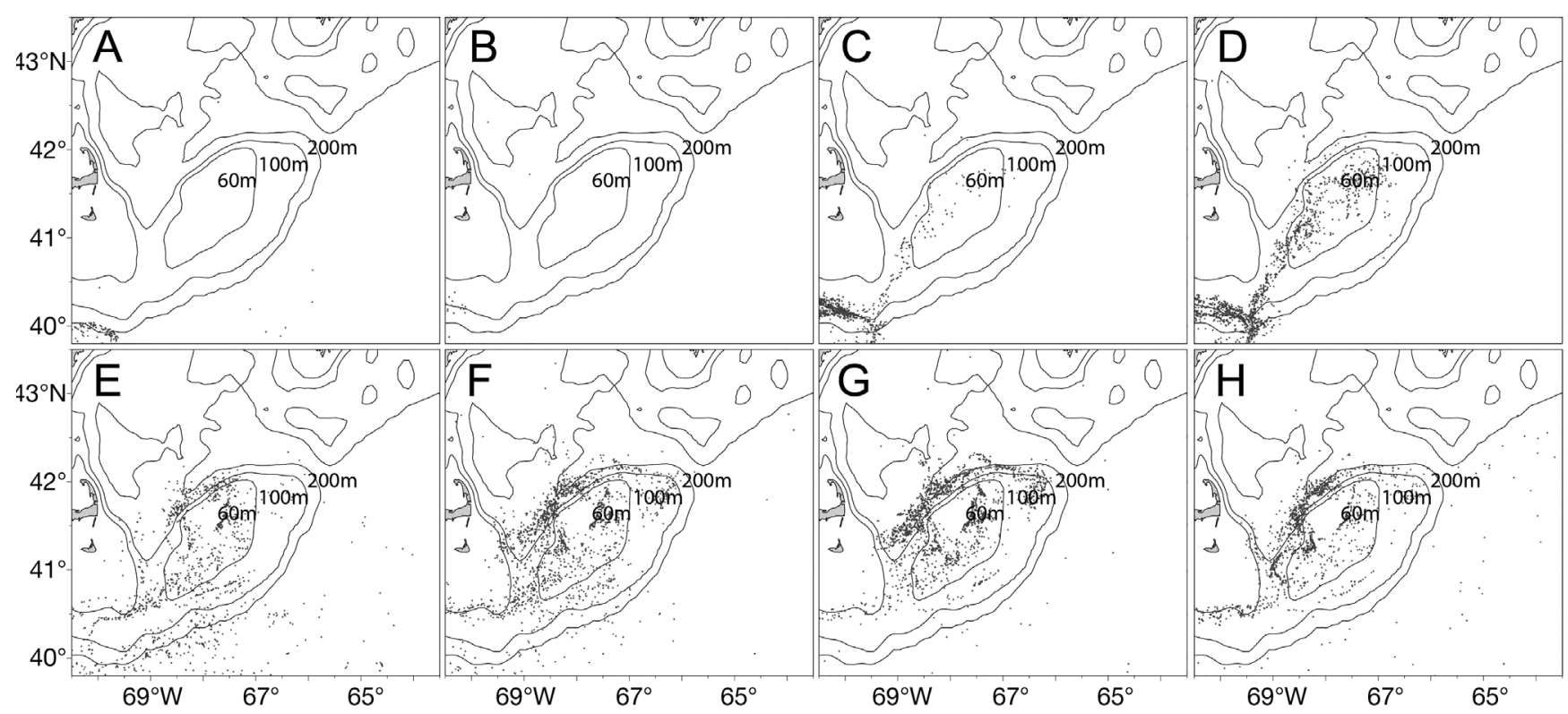

Fig. 6. Comparison of the retention of haddock larvae on Georges Bank in 1998 after 90 d, with (A-D) local forcing (GoM1FVCOM) and (E-H) combined local and remote forcing (GoM3-FVCOM) at (A,E) $1 \mathrm{~m},(\mathrm{~B}, \mathrm{~F}) 10 \mathrm{~m},(\mathrm{C}, \mathrm{G}) 30 \mathrm{~m}, \mathrm{and}(\mathrm{D}, \mathrm{H}) 50 \mathrm{~m}$ release depths simulated with vertical turbulence

Table 1. Comparison of age-1 recruitment success of the Georges Bank haddock stock with model-generated retention rate (\%) estimates for 1995 through 2009. Highest recruitment success and retention occurred in 2003

\begin{tabular}{|lcc|}
\hline & Retention rates (\%) & Recruitment success \\
\hline 1995 & 46.92 & 0.47 \\
1996 & 23.45 & 0.33 \\
1997 & 15.45 & 0.54 \\
1998 & 31.02 & 0.97 \\
1999 & 15.24 & 0.20 \\
2000 & 58.89 & 1.23 \\
2001 & 42.36 & 0.06 \\
2002 & 22.77 & 0.03 \\
2003 & 61.97 & 3.46 \\
2004 & 54.37 & 0.07 \\
2005 & 23.86 & 0.23 \\
2006 & 16.01 & 0.03 \\
2007 & 16.76 & 0.04 \\
2008 & 47.99 & 0.02 \\
2009 & 24.91 & 0.04 \\
\hline
\end{tabular}

2005, Kristiansen et al. 2007), but the impact of vertical diffusion on depth-dependent transport has not been analyzed in detail for Georges Bank, where displacement may be out of the control of small, pelagic organisms. The potential for buoyancy and vertical behavior to alter the vertical displacement of individuals on Georges Bank was not included in this study and requires additional investigation.

\section{Anatomy of high versus low retention years}

The 3 general pathways for the transport of larvae around Georges Bank consist of transport from the Northeast Peak: (1) recirculated around the Bank, (2) advected over the Great South Channel and onto the Mid-Atlantic Bight, or (3) advected into the North Atlantic or interior Gulf of Maine region due to a 'leaky' gyre. Interannual variability in the circulation of the Gulf of Maine-Georges Bank region caused retention rates and distributions to differ substantially between years, with patterns common to high and low retention years emerging. One year of high (2003) and low (1997) retention are compared here.

The disparity in retention between 1997 and 2003 is a result of the advective dynamics in the environment. The physical processes of 1997 and 2003 differed substantially in circulation patterns and velocity, frontal system dynamics, and stratification. In 1997, surface currents exhibited increased velocities recirculating around the gyre at the shelf break and southwest over the Great South Channel (Fig. 7A-C). Currents on the southwest of the gyre were insufficient to recirculate eggs and larvae around Georges Bank, resulting in increased advective losses. In comparison, the surface currents in 2003 were reduced, decreasing the transport speed of individuals around the gyre (Fig. 7D-F). The slow meandering of the current reduced advective losses to the Mid-Atlantic Bight, and increased transport to the shoals. 
Tidal-mixing and shelf-break fronts serve as barriers, entraining eggs and larvae within the Georges Bank gyre and reducing advective losses, but vary in intensity and location on seasonal and interannual scales (Townsend \& Pettigrew 1996, Chen et al. 2003). The gyre functions as a corral to retain individuals on Georges Bank in most years, but variability in water mass density, current speed, and wind intensity impact the dynamics of the shelf-break and tidalmixing fronts.

Spatially and temporally reduced intensity of the fronts around Georges Bank produces a 'leaky' gyre with substantial losses, caused by currents and wind events. In 1997, the frontal dynamics exhibited extensive spatial and temporal distributions around Georges Bank, creating a persistent horseshoeshaped barrier open to the southwest (Fig. 8). The fronts corralled individuals within the gyre, limiting losses off the edges; however, reduced frontal distribution and intensity at the Great South Channel enabled advection of larvae onto the Mid-Atlantic Bight. Diminished frontal dynamics in 2003 created a 'leaky' gyre, with losses off the edges of Georges Bank to the North Atlantic and interior Gulf of Maine, but increased intensity of the fronts in the
Great South Channel provided greater recirculation than in 1997.

Variability in the fronts between years is directly impacted by gyre circulation. Current speed and direction on Georges Bank are influenced by winds, runoff, and flow from the Arctic, but locally the clockwise gyre around Georges Bank is enhanced by stratification and tidal rectification (Loder \& Wright 1985, Chen et al. 1995). Onset and intensification of stratification in 1997 and 2003 differed substantially (Fig. 9). In 1997 stratification developed by May, intensifying gyre circulation; while in 2003 stratification was delayed until June. Increased intensities of the gyre velocities, tidal rectification, and tidal-mixing fronts in 1997 generated a pathway to quickly transport individuals onto the Mid-Atlantic Bight. Slower currents, increased frontal formation in the Great South Channel, and delayed onset of stratification resulted in a meandering, leaky gyre with increased retention of larval haddock on Georges Bank during the spring of 2003.

The inability of the retention estimates to reflect large recruitment events can be attributed to the dynamic nature of recruitment. Retention estimates in 2000 and 2003 were the highest obtained from the
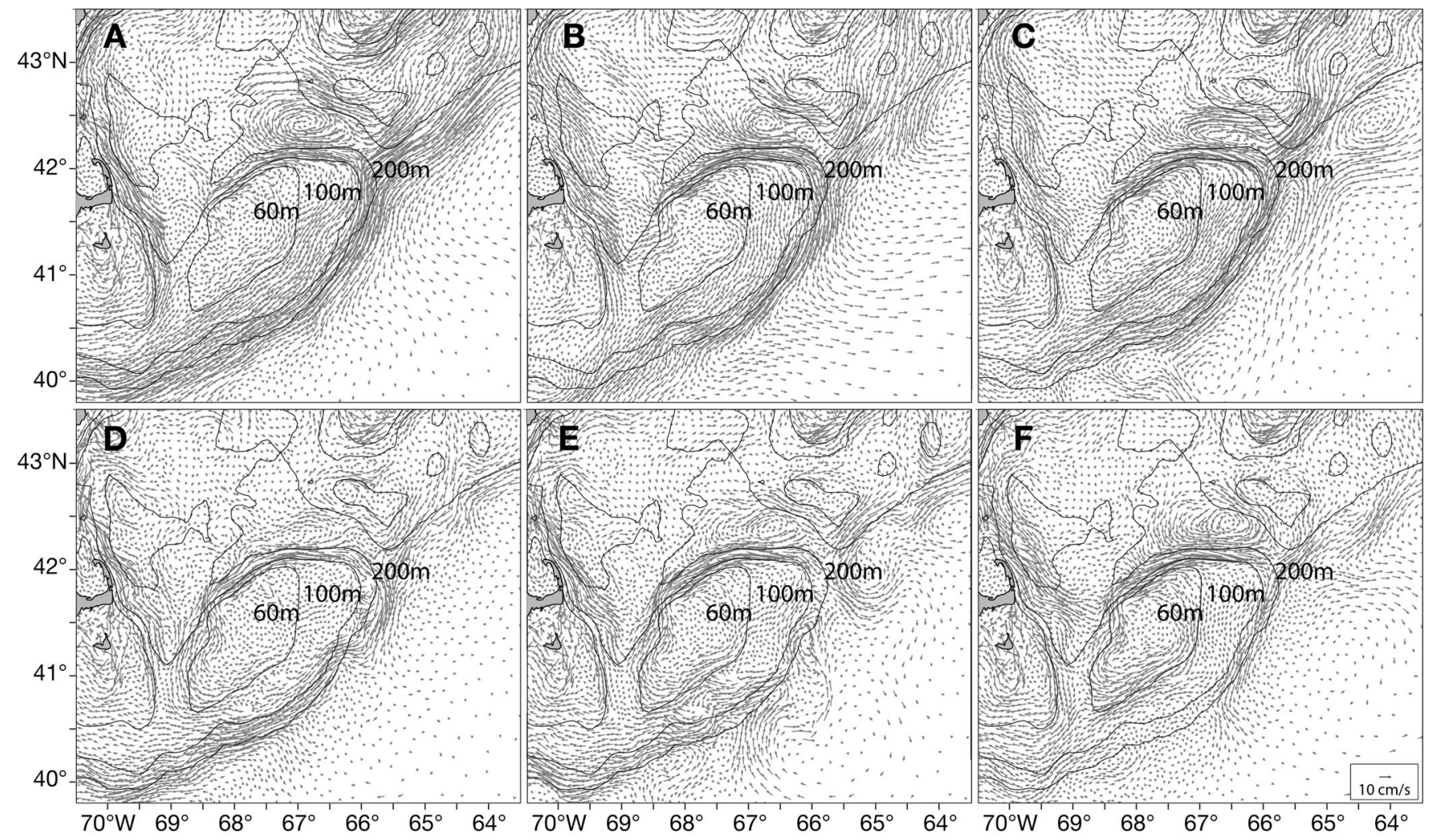

Fig. 7. Comparison of monthly-averaged surface currents on Georges Bank in (A-C) 1997 and (D-F) 2003 in (A,D) April, (B,E) May, and (C,F) June with GoM1-FVCOM physical forcing 

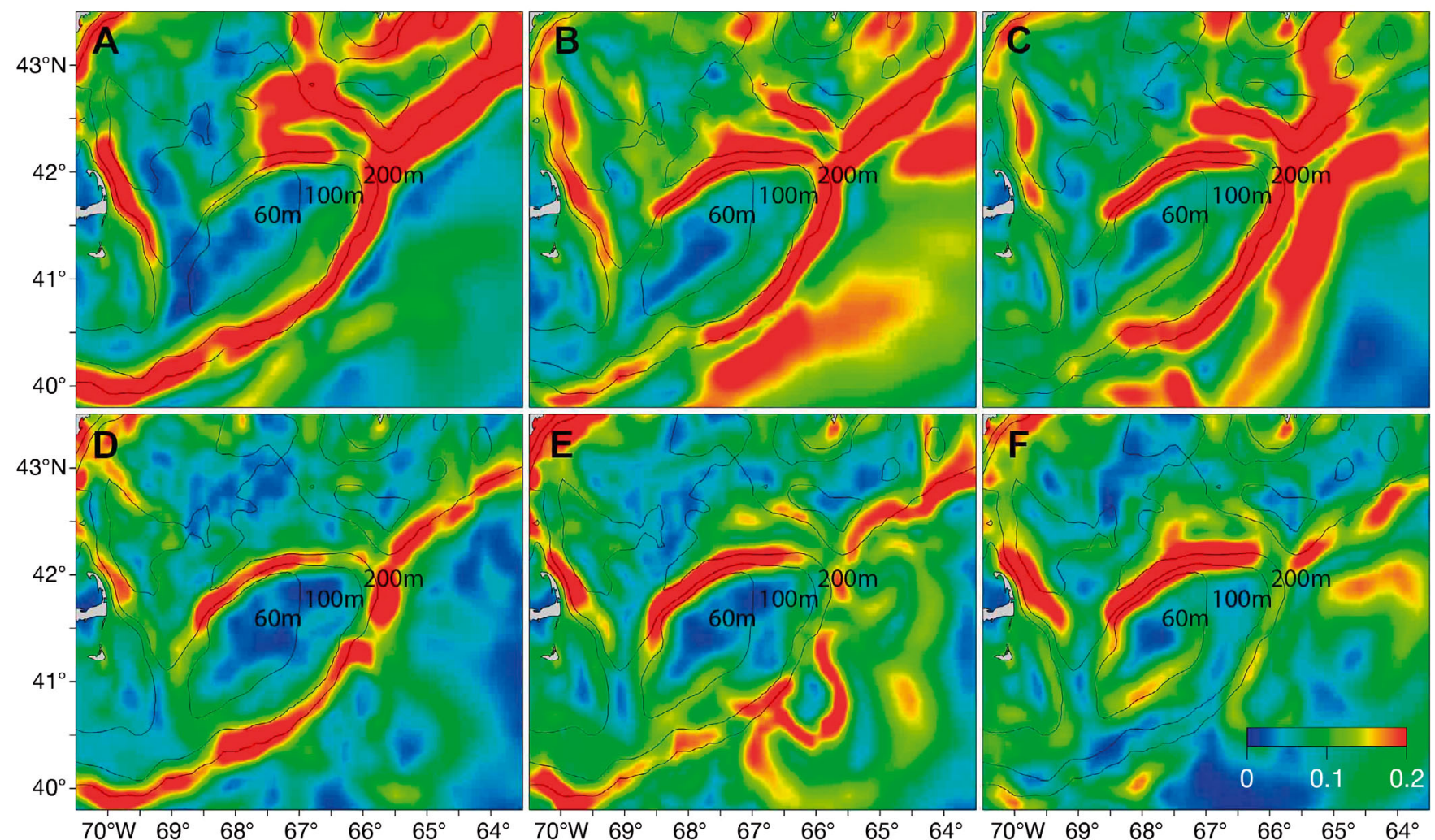

Fig. 8. Comparison of monthly-averaged frontal systems on Georges Bank in (A-C) 1997 and (D-F) 2003, in (A,D) April, (B,E) May, and $(\mathrm{C}, \mathrm{F})$ June, with GoM1-FVCOM physical forcing. Frontal systems are determined as the ratio (color scale) of shear dispersion in the surface layer and bottom layer of the circulation model

simulations and coincided with the 2 highest recruitment success values. Retention in 2004 was only $4.52 \%$ lower than in 2000, but had low recruitment success. The larger recruitment events may be attributed in part to circulation patterns allowing the larvae and their prey to remain on Georges Bank, but reduced predation or enhanced foraging and growth may provide the key mechanism to understanding survival rates of anomalously large events.

From spawning until juvenile settlement, haddock on Georges Bank experience a highly dynamic environment with limited control over dispersal or transport to nursery areas (Lough \& Bolz 1989). The primary factor influencing retention was the circulation speed of the gyre. Retention was low in years with high flow rates throughout the Gulf of Maine and around Georges Bank, increasing as circulation intensity decreased. Inflow over the Scotian Shelf and slope increased flow rates throughout the coastal Gulf of Maine and intensified recirculation around Georges Bank. The dominance of large-scale processes persists over the $15 \mathrm{yr}$ period, with tidal interaction, stratification, and tidal rectification further altering the intensity of the gyre. A combination of circulation, vertical mixing, and the onset of stratification created an 'optimal environmental window' (Cury \& Roy 1989) for retention, with the timing and duration highly variable between years.

\section{Influence of remote forcing}

The flow fields generated by the GoM1-FVCOM for 1998 do not accurately reflect observations from the region. The lack of association between our retention estimates and haddock recruitment in this year is consistent with results for a lower trophic level from a food web model by Tian et al. (unpubl.), who reported that the model-predicted chlorophyll a concentration showed a significant bias to observed values on Georges Bank.

The GoM1-FVCOM is an early version of FVCOM for the Gulf of Maine, which did not include transport input from the upstream shelf and slope regions connected to the Labrador Sea and Arctic Ocean. The Gulf of Maine exhibited a large salinity anomaly 

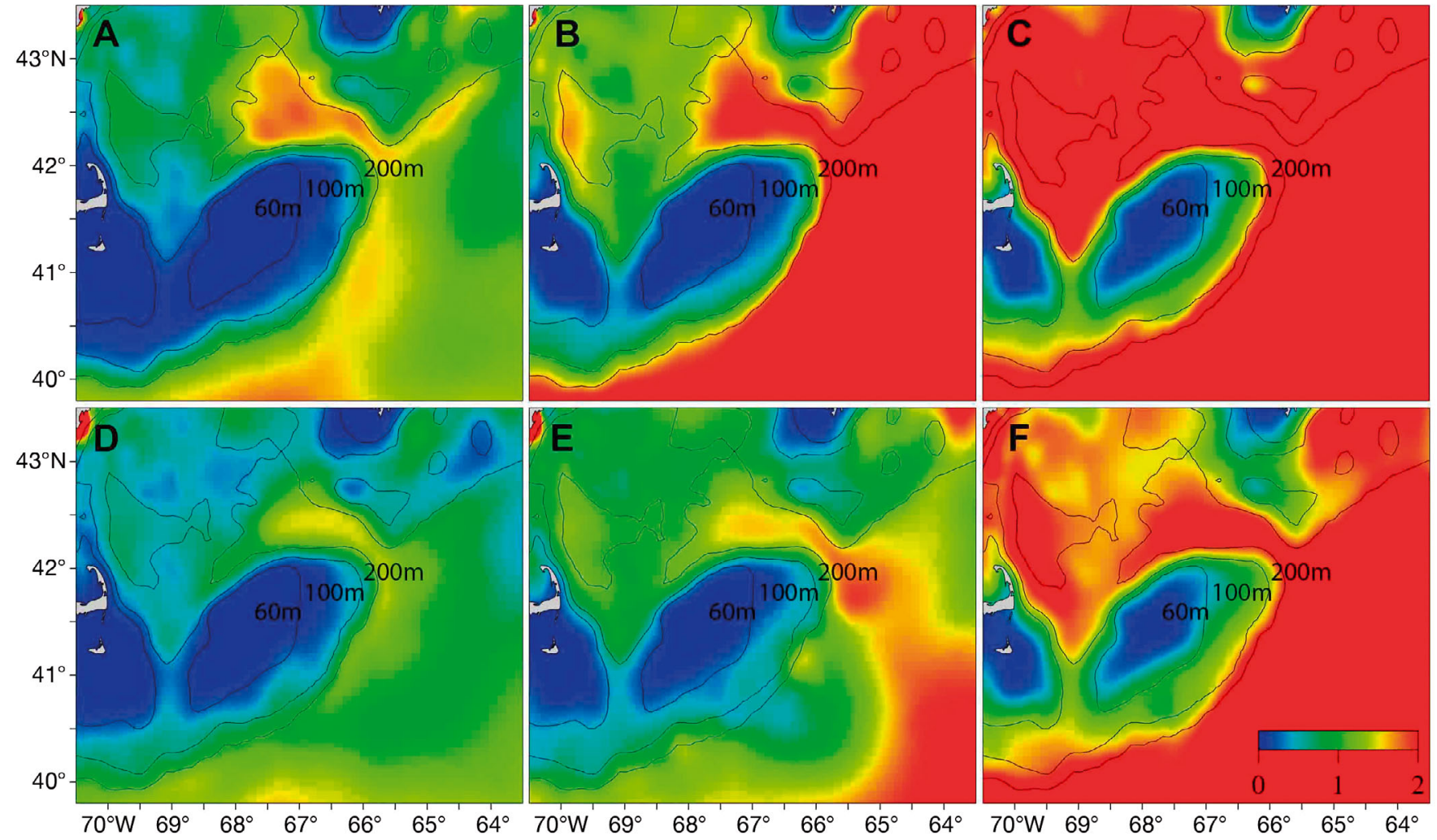

Fig. 9. Comparison of monthly-averaged stratification on Georges Bank in (A-C) 1997 and (D-F) 2003, in (A,D) April, (B,E) May, and $(\mathrm{C}, \mathrm{F})$ June, with GoM1-FVCOM physical forcing. Stratification is determined as the ratio (color scale) of water density in the sur-face layer and bottom layer of the circulation model

in 1998, with significant influence by water transport from the upstream region. Failure of the GoM1FVCOM to produce a retention estimate comparable to recruitment in 1998 was assumed to be due to the exclusion of remote forcing. The GoM1-FVCOM circulation exhibited strong currents flowing from the northeast, enhancing the gyre around the bank and flowing over the Great South Channel, while the GoM3-FVCOM circulation exhibited decreased flow over the Scotian Shelf, reduced current speed over the Northeast Channel, and increased recirculation of the gyre around the shoal region of Georges Bank (Fig. S4 in the Supplement). We hypothesized that the low retention estimate for 1997 would not increase substantially with the addition of remote forcing, as recruitment estimates for that year were the lowest of the study period (NFSC 2012). It was assumed that the GoM1-FVCOM circulation accurately represented the dynamics for 1997, while remote forcing was inaccurately represented for 1998.

The low retention estimates obtained for 1997 and 1998 with the GoM1-FVCOM were increased when the GoM3-FVCOM forcing was implemented
(Figs. S1 \& S3 in the Supplement). The influence of remote forcing on transport to the shoals of Georges Bank appears to vary by year, increasing by $13.73 \%$ in 1997 and $29.94 \%$ in 1998. Interannual variability in the model occurs through 2 primary components: (1) local (winds, precipitation/evaporation, heat flux, freshwater discharge) and (2) remote (inflow from the boundaries). GoM1-FVCOM includes local forcing and limited remote forcing over the Scotian Shelf, but lacks flow over the slope. The increased retention estimates for both 1997 and 1998 indicate that inclusion of remote forcing in the Gulf of Maine is necessary for interpreting transport-retention dynamics, with slope water interaction essential in some years. The dynamic nature of remote forcing may have a positive effect on haddock retention, but further study is necessary to determine if this trend persists between additional years. Circulation models that rely primarily on local forcing may neglect important sources of variability for the Gulf of Maine-Georges Bank region, making them insufficient for studies involving large-scale dynamics such as climate change. 


\section{CONCLUSIONS}

The retention of a cohort is altered by dynamic interactions with the physical environment on multiple spatial and temporal scales, with eggs and larvae subjected to highly variable winds, currents, temperatures, and resulting transport velocities. Individuals residing lower in the water column, where the influence of wind-driven transport declines, were more likely to be retained on Georges Bank. However, the depth of spawning does not have a substantial influence on vertical distribution over the entire pelagic duration, when individuals encounter intense vertical mixing on Georges Bank. Development of swimming behaviors by larvae over ontogeny may not be necessary for substantial shoalward transport in all years, but provides an essential mechanism when strong off-bank transport exists in the upper water column.

In all years the majority of advective losses from the nursery area occurred over the Great South Channel, with retention dependent upon recirculation around the southern flank of Georges Bank. The intensity and distribution of the tidal-mixing and shelf-break fronts comprised the primary regulating factor for retention. Increased retention occurred in years when the fronts formed earlier in the Great South Channel and recirculating currents persisted on the southern flank. Greater advection off-bank was predominant when fronts were absent or minimal in the Great South Channel and strong advective currents off of the southern flank occurred.

Inflow of colder, fresher waters from the Arctic over the Scotian Shelf and slope influence current velocity and water mass density in the Gulf of Maine, directly impacting the onset of stratification and formation of frontal systems around Georges Bank. Circulation models capable of resolving time-varying remote forcing in the Gulf of Maine region are essential for studies of transport-retention dynamics on Georges Bank and should be considered for future studies involving IBMs.

Acknowledgements. This research is supported by the U.S. GLOBEC Northwest Atlantic/Georges Bank Program NSF (OCE-0234545, 0227679, 0606928, 0726851 and 0814505. The GoM3-FVCOM product was built with support from the NOAA NERACOOS and Massachusetts Ocean Partnership (MOP) (renamed SeaPlan in 2012) programs. C.C. was also supported by the Shanghai Ocean University International Cooperation Program (No. A-2302-11-0003), the Program of Science and Technology Commission of Shanghai Municipality (No. 09320503700) and the Leading Academic Discipline Project of Shanghai Municipal Education Commission
(Project number J50702). The authors thank Rucheng Tian and Pengfei Xue for their assistance in developing the IBM; and also Brian Rothschild, Steven X. Cadrin, Jon Hare, and Rubao Ji for their valuable comments and suggestions throughout this project.

\section{LITERATURE CITED}

Auditore PJ, Lough RG, Broughton EA (1994) A review of the comparative development of Atlantic cod (Gadus morhua) and haddock (Melanogrammus aeglefinus) based on an illustrated series of larvae and juveniles from Georges Bank. J Northwest Atl Fish Sci 20:7-18

$>$ Bartsch J, Coombs SH (2001) An individual-based growth and transport model of the early life history stages of mackerel (Scomber scombrus) in the eastern North Atlantic. Ecol Model 138:127-141

Bartsch J, Coombs SH (2004) An individual-based model of the early life history of mackerel (Scomber scombrus) in the eastern North Atlantic, simulating transport, growth and mortality. Fish Oceanogr 13:365-379

> Beardsley RC, Lentz SJ, Weller RA, Limeburner R, Irish JD, Edson JB (2003) Surface forcing on the southern flank of Georges Bank, February-August 1995. J Geophys Res 108:8007, doi:10.1029/2002JC001359

Beyer JE (1989) Recruitment stability and survival — simple size-specific theory with examples from the early life dynamics of marine fish. Dana 7:45-47

> Brickman D (2003) Controls on the distribution of Browns Bank juvenile haddock. Mar Ecol Prog Ser 263:235-246

> Brickman D, Frank K (2000) Modelling the dispersal and mortality of Browns Bank egg and larval haddock (Melanogrammus aeglefinus). Can J Fish Aquat Sci 57: 2519-2535

Brink KH, Chapman DC, Halliwell GR Jr (1987) A stochastic model for wind-driven currents over the continental shelf. J Geophys Res 92:1783-1797, doi:10.1029/JC092iC $02 \mathrm{p} 01783$

Brodziak J, Traver M, Col L, Sutherland S (2006) Stock assessment of Georges Bank haddock, 1931-2004. Northeast Fisheries Science Center, Ref Doc 06-11. NEFSC, Woods Hole, MA

Chapman DC, Beardsley RC (1989) On the origin of shelf water in the Middle Atlantic Bight. J Phys Oceanogr 19: 384-391

Chase J (1955) Winds and temperatures in relation to the brood-strength of Georges Bank haddock. J Cons Int Explor Mer 21:17-24

> Chen C, Beardsley RC, Limeburner D (1995) A numerical study of stratified tidal rectification over finite-amplitude banks. II. Georges Bank. J Phys Oceanogr 25:2111-2128

> Chen C, Beardsley RC, Franks PJS (2001) A 3-D prognostic model study of the ecosystem over Georges Bank and adjacent coastal regions. I. Physical model. Deep-Sea Res 48:419-456

> Chen C, Schlitz R, Lough C, Smith K, Beardsley R, Manning $J$ (2003) Wind-induced cross-frontal water transport on the southern flank of Georges Bank: a physical mechanism for the cross-frontal fish larval transport in early summer. J Geophys Res 108:8011, doi:10.1029/2002JC 001358

> Chen C, Beardsley RC, Cowles GW (2006) An unstructuredgrid, Finite-Volume Coastal Ocean Model (FVCOM) system. Oceanography 19:78-89 
Chen C, Huang H, Beardsley RC, Liu H, Xu Q, Cowles GW (2007) A finite volume numerical approach for coastal ocean circulation studies: comparisons with finite difference models. J Geophys Res 112:C03018, doi:10.1029/ 2006JC003485

Chen C, Haung H, Beardsley RC, Xu Q and others (2011) Tidal dynamics in the Gulf of Maine and New England Shelf: an application of FVCOM. J Geophys Res 116: C12010, doi:10.1029/2011JC007054

> Churchill JH, Runge J, Chen C (2011) Processes controlling retention of spring-spawned Atlantic cod (Gadus morhua) in the western Gulf of Maine and their relationship to an index of recruitment success. Fish Oceanogr 20:32-46

> Colton JB Jr, Temple RF (1961) The enigma of Georges Bank spawning. Limnol Oceanogr 6:280-291

> Cury P, Roy C (1989) Optimal environmental window and pelagic fish recruitment success in upwelling areas. Can J Fish Aquat Sci 46:670-680

Cushing DH (1974) The possible density-dependence of larval mortality and adult mortality in fishes. In: Blaxter JHS (ed) The early life history of fish. Springer-Verlag, Berlin, p 103-111

> Drinkwater KF, Gilbert D (2004) Hydrographic variability in the waters of the Gulf of St. Lawrence, the Scotian Shelf and the Eastern Gulf of Maine (NAFO Subarea 4) during 1991-2000. J Northwest Atl Fish Sci 34:85-101

Flierl GR, Wroblewski JS (1985) The possible influence of warm core Gulf Stream rings upon shelf water larval fish distribution. Fish Bull 83:313-330

Franks PJS, Chen C (1996) Plankton production in tidal fronts: a model of Georges Bank in summer. J Mar Res 54:631-651

Grimm V, Berger U, Bastiansen F, Eliassen S and others (2006) A standard protocol for describing individualbased and agent-based models. Ecol Model 198:115-126

Hardy JD (1978) Development of fishes of the Mid-Atlantic Bight: an atlas of egg, larval and juvenile stages. Vol. 2: Anguillidae through Syngnathidae. US Fish Wildl Serv Biol Serv Program FWS/OBS-78/12

Hjort J (1914) Fluctuations in the great fisheries of northern Europe viewed in the light of biological research. Rapp Cons Int Explor Mer 20:1-228

Hopkins TS, Raman S (1987) Atmospheric variables and patterns. In: Backus RH (ed) Georges Bank. MIT Press, Cambridge, MA, p 66-73

Horne EPW, Loder JW, Harrison WG, Mohn R, Lewis MR, Irwin B, Platt T (1989) Nitrate supply and demand at the Georges Bank tidal front. Sci Mar 53:145-158

$\mathrm{Hu}$ S (2009) Variability of physical forcing and its impacts on nutrient supplies and fall phytoplankton blooms in the Gulf of Maine-Georges Bank region. PhD dissertation, University of Massachusetts, North Dartmouth, MA

Hughes TP, Bellwood DR, Connolly SR (2002) Biodiversity hotspots, centres of endemicity, and the conservation of coral reefs. Ecol Lett 5:775-784

Kristiansen T, Fiksen O, Folkvord A (2007) Modelling feeding, growth, and habitat selection in larval Atlantic cod (Gadus morhua): observations and model predictions in a macrocosm environment. Can J Fish Aquat Sci 64: 136-151

Lasker R (1975) Field criteria for survival of anchovy larvae: the relation between inshore chlorophyll maximum layers and successful first feeding. Fish Bull 73:453-462 Limeburner R, Beardsley RC (1996) Near-surface recircula- tion over Georges Bank. Deep-Sea Res II 43:1547-1574

Loder J (1980) Topographic rectification of tidal currents on the sides of Georges Bank. J Phys Oceanogr 10:1399-1416

Loder JW, Wright DG (1985) Tidal rectification and frontal circulation on the sides of Georges Bank. J Mar Res 43: 581-604

Lough RG, Bolz GR (1989) The movement of cod and haddock larvae onto the shoals of Georges Bank. J Fish Biol 35(Suppl A):71-79

Lough RG, Smith WG, Werner FE, Loder JW and others (1994) Influence of wind-driven advection on the interannual variability in cod egg and larval distributions on Georges Bank: 1982 vs 1985. ICES Mar Sci Symp 198: 356-378

Lough RG, Hannah CG, Berrien P, Brickman D, Loder JW, Quinlan JA (2006) Spawning pattern variability and its effect on retention, larval growth and recruitment in Georges Bank cod and haddock. Mar Ecol Prog Ser 310: 193-212

> Mellor GL, Yamada T (1982) Development of a turbulence closure model for geophysical fluid problems. Rev Geophys 20:851-875, doi:10.1029/RG020i004p00851

> Miller JE (1946) Cyclogenesis in the Atlantic coastal region of the United States. J Atmos Sci 2:31-44

> Mountain D, Green J, Sibunka J, Johnson D (2008) Growth and mortality of Atlantic cod Gadus morhua and haddock Melanogrammus aeglefinus eggs and larvae on Georges Bank, 1995 to 1999. Mar Ecol Prog Ser 353:225-242

NFSC (Northeast Fisheries Science Center) (2012) Assessment or data updates of 13 Northeast groundfish stocks through 2010. NFSC Ref Doc. 12-06

O'Reilly JE, Evans-Zetlin CE, Busch DA (1987) Primary production. In: Backus RH (ed) Georges Bank. MIT Press, Cambridge, MA

> Page FH, Frank KT (1989) Spawning time and egg stage duration in Northwest Atlantic haddock (Melanogrammus aeglefinus) stocks with emphasis on Georges and Browns Bank. Can J Fish Aquat Sci 46(Suppl. 1):68-81

Page FH, Frank KT, Thompson KR (1989) Stage dependent vertical distribution of haddock (Melanogrammus aeglefinus) eggs in a stratified water column: observations and model. Can J Fish Aquat Sci 46(Suppl. 1):55-67

> Polacheck T, Mountain D, McMillan D, Smith W, Berrien P (1992) Recruitment of the 1987 year class of Georges Bank haddock (Melanogrammus aeglefinus): the influence of unusual larval transport. Can J Fish Aquat Sci 49: 484-496

> Reese DC, Brodeur RD (2006) Identifying and characterizing biological hotspots in the northern California Current. Deep-Sea Res II 53:291-314

Riley GA (1941) Plankton studies. III. Long Island Sound. Bull Bingham Oceanogr Collect Yale Univ 7:1-93

Rothschild BJ (1986) Dynamics of marine fish populations. Harvard University Press, Cambridge, MA

> Sale P (1978) Coexistence of coral reef fishes-a lottery for living space. Environ Biol Fishes 3:85-102

Sibunka JD, Johnson DL, Berrien PL (2006) Distribution and abundance of fish eggs collected during the GLOBEC broad-scale Georges Bank surveys, 1995-1999. NOAA Tech Memo NMFS-NE-199

> Smagorinsky J (1963) General circulation experiments with the primitive equations: I. The basic experiment. Mon Weather Rev 91:99-164

Smith WG, Morse WW (1985) Retention of larval haddock Melanogrammus aeglefinus in the Georges Bank region, 
a gyre-influenced spawning area. Mar Ecol Prog Ser 24: $1-13$

Smith P, Houghton RW, Fairbanks RG, Mountain DG (2001) Interannual variability of boundary fluxes and water mass properties in the Gulf of Maine and on Georges Bank. Deep-Sea Res II 48:37-70

Sun Y, Chen C, Beardsley RC, Xu Q, Qi J, Lin H (2013) Impact of current-wave interaction on storm surge simulation: a case study for Hurricane Bob. J Geophys Res Oceans 118, doi:10.1002/jgrc.20207

Tian RC, Chen C, Stokesbury KDE, Rothschild BJ and others (2009) Dispersal and settlement of sea scallop larvae spawned in the fishery closed areas on Georges Bank. ICES J Mar Sci 66:2155-2164

Townsend DW, Pettigrew NR (1996) The role of frontal currents in larval fish transport on Georges Bank. Deep-Sea Res II 43:1773-1792

Townsend DW, Pettigrew NR (1997) Nitrogen limitation of secondary production on Georges Bank. J Plankton Res 19:221-235

Valavanis VD, Dapantagakis A, Katara I, Palialexis A (2004)

Submitted: July 7, 2012; Accepted: June 28, 2013
Critical regions: a GIS-based model of marine productivity hotspots. Aquat Sci 66:139-148

Vikebo F, Sundby S, Adlandsvik B (2005) The combined effect of transport and temperature on distribution and growth of larvae and pelagic juveniles of ArctoNorwegian cod. ICES J Mar Sci 62:1375-1386

> Visser AW (1997) Using random walk models to simulate the vertical distribution of particles in a turbulent water column. Mar Ecol Prog Ser 158:275-281

> Werner FE, Page FH, Lynch DR, Loder JW and others (1993) Influences of mean advection and simple behavior on the distribution of cod and haddock early life stages on Georges Bank. Fish Oceanogr 2:43-64

Werner FE, Perry RI, Lough RG, Naimie CE (1996) Trophodynamic and advective influences on Georges Bank larval cod and haddock. Deep-Sea Res II 43:1793-1822

> Werner FE, MacKenzie BR, Perry RI, Lough RG, Naimie CE, Blanton BO, Quinlan JA (2001) Larval trophodynamics, turbulence, and drift on Georges Bank: a sensitivity analysis of cod and haddock. Sci Mar 65(Suppl. 1): 99-115

Proofs received from author(s): July 19, 2013 